\title{
ANNOUNCING
}

\section{THE SIXTH ANNUAL HISTORY OF ECONOMICS SOCIETY CONFERENCE, MAY 24-26, 1979}

\section{INFORMATION REGARDING ARRANGEMENTS:}

Location: The campus of the University of Illinois at Urbana-Champaign. Champaign and Urbana are contiguous cities located roughly equidistant from Chicago, Indianapolis, and St. Louis (about 125 miles from the first two; 160 miles from the last).

Transportation: Ozark Airlines has direct (and in some cases non-stop) flights from Chicago, St. Louis, Denver, Washington and New York City. The Champaign airport is a part of the University and is about a ten minute drive from the campus.

There is Amtrak rail service from Chicago and New Orleans and bus service between these points (as well as East-West bus service).

The twin cities lie at the intersection of Interstate Highway Routes 57,72 , and 74 .

Housing: The Illini Union on the campus of the University. All rooms are air-conditioned, of generous size, with private bath and color television. Rates are very reasonable. For those preferring complete hotel services (including bar service), a nearly new hotel is four blocks away. Details of rates and reservations will be sent to members about April 1.

Sessions: The sessions and the business meeting will be held in the Illini Union.

Social Events: These will be in the Faculty Center about four blocks from the Illini Union. There will be a social hour followed by a banquet on Thursday evening, May 24. On Friday afternoon, May 25, the Chancellor will host a social hour for those attending the Conference.

Exhibit: The University Library's Rare Book Room will mount an exhibit of items drawn from the Hollander Collection. Information on the Collection will be found elsewhere in this Bulletin. 